\title{
ADMINISTRATIVE JUSTICE IN FRANCE. BETWEEN SINGULARITY AND CLASSICISM
}

\author{
HUGO FLAVIER, \\ University of Bordeaux (Bordeaux, France) \\ CHARLES FROGER, \\ Paris-Sorbonne University (Paris, France)
}

DOI: $10.21684 / 2412-2343-2016-3-2-80-111$

The administrative justice in France oscillates between classicism and singularity. Multiple factors explain how administrative justice has come to occupy a particular place in French administrative law. Administrative justice has not only settled disputes between administration and private persons, but as well, built the French administrative law. One of the main tasks during 19th and 20th century consisted in strengthen the independence from the executive branch and the efficiency in order to satisfy the idea of good justice. Many reforms have been led since the 1990's. That is why we propose to depict the French system and evaluate the activity of French administrative justice concerning the judicial organization, its jurisdiction and the remedies before the administrative judge. We will enlighten also our paper with a comparative approach and some statistical elements.

Key words: administrative justice; French civil procedure.

Recommended citation: Hugo Flavier, Charles Froger, Administrative Justice in France. Between Singularity and Classicism, 3(2) BRICS Law Journal 80-111 (2016).

\section{Table of contents}

\section{Introduction}

\section{Judicial Organisation}

\subsection{The Administrative Courts}

2.1.1. The Ordinary Administrative Courts 
2.1.1.1. The Conseil d'État

2.1.1.2. The Administrative Courts and Administrative Courts of Appeal

2.1.2. The Specialist Administrative Courts

\subsection{Administrative Judges}

2.2.1. Members of the Conseil d'État

2.2.2. Judges of the Administrative Courts and Administrative Courts of Appeal

3. The Jurisdiction of the Administrative Courts

3.1. The Principle of Separation

3.1.1. Grounds of Jurisdiction

3.1.2. Exceptions to Jurisdiction

\subsection{Protecting the Separation}

4. The Remedies Available before the Administrative Court

4.1. The Distinction between Actions on Grounds of Ultra Vires and Full Remedy Proceedings

4.1.1. Actions on Grounds of Ultra Vires

4.1.2. Full Remedy Proceedings

4.2. Developments in the Distinction

4.2.1. The New Action on Grounds of Ultra Vires

4.2.2. Overhauling Full Remedy Proceedings

4.3. The Emergence of the Question Prioritaire de Constitutionnalité

5. Fundamental Principles Applicable to Administrative Proceedings

5.1. Principles Governing the Organisation of Justice

5.2. Principles Relating to the Fairness of Proceedings

6. A Comparative Approach

6.1. The Influence of French Administrative Justice in Europe

6.2. The Influence of European Laws on the French Administrative Justice

6.2.1. The Influence of EU and ECHR Law on Administrative Justice

6.2.1.1. The Extension of the Administrative Court's Powers

6.2.1.2. Changes to Administrative Trials

6.2.1.3. State Liability for the Activities of Administrative Justice

6.2.2. French Administrative Justice under the Influence of European Administrative Laws

7. Statistical Elements

7.1. The Conseil d'Etat's Advisory Activities in 2015

7.2. The Jurisdictional Activities of the Administrative Courts in 2015 


\section{Introduction}

If there is a country where it can be difficult to distinguish between administrative justice and substantive administrative law, it is France. The judicial body and the subject matter are inextricably linked to its existence and, probably for a long time yet, to its future. Historical foundations, cultural reflexes, national legal tradition multiple factors explain how administrative justice has come to occupy a particular and preponderant - place in French administrative law.

Under the Ancien Régime, what could be termed administrative matters were the purview of the intendants and of the Conseil du Roi (King's Council). The Edict of SaintGermain 1641 thus forbade that the parlements' should hear cases concerning State affairs. More specifically, it provided that the parlements and the Court of Paris "have been established only in order to give justice to our subject" and that the King had issued to them "very express inhibitions and prohibitions, not only to hear, in future, cases similar to those heretofore set, but generally those which may concern the state, administration and government." ${ }^{\prime 2}$ Nevertheless, the parlements did not abandon their judicial activism. In the name of the separation of powets under Article 16 of the Declaration of the Rights of Man and of the Citizen, ${ }^{3}$ the French Revolution continued that trend by distinguishing between that which belongs to the judicial order and that which belongs to the administrative order, and therefore to the State and the Executive respectively. The Law of 16-24 August 1790 on judicial organisation, which is still in force, thus prescribes at Article 13 that "judicial functions are separate and shall always remain separate from administrative functions. Courts shall not, on pain of forfeiture, disrupt in any way the operation of administrative bodies, or summon administrators to appear before them by reason of their duties/functions."14 This rule was reaffirmed - as it had not been respected - by the Decree of 16 Fructidor Year III, according to which "iterative prohibitions are made to the courts to review administrative acts, of whatever kind, subject to the penalties provided by law." The foundations of the specificity of administrative justice were thus laid. The State's administrative activities/actions must not be hindered by a court that does not know about those activities and the judicial branch cannot involve itself in matters relating to the exercise of executive power. It is unsurprising, therefore, that in order to settle disputes that arose, it was the minister himself, as the higher authority and guarantor of the proper operation

It is not Parliament within the meaning given to it today. The Parlements under the Ancien Régime were ordinary courts.

2 Recueil général des anciennes lois françaises, depuis l'an 420 jusqu'à la Révolution de 178, t. XVI 529 (Isambert et Taillandier, Paris 1829).

3 Art.16: "Any society in which the guarantee of rights is not assured, nor the separation of powers, has no Constitution."

4 This legislation was the subject of a question prioritaire de constitutionnalité (QPC) which was not passed on by the Court of Cassation (Cass. Civ., 2e, 21 June 2012, No. 1342 of 21 June 2012). 
of his ministry (and, beyond that, of the general interest), had to rule on a given case. This is the theory of the minister as judge. ${ }^{5}$

The essential function/role of the Conseil d'État, which institution was established in 1799 by Napoleon Bonaparte ${ }_{,}^{6}$ consisted at that time in advising the holder of executive power - be it the Emperor, the King or the Government, depending on the period. However, the executive branch generally followed the opinions given by the Conseil d'État, and to such an extent that it might be said that in practice, decisions were made by the Conseil d'État itself. The Law of 24 May 1872 formalised that role/ function, thus poutting an end to the existing justice system in order to adopt one based on delegated justice. From that point on, the Conseil d'État ruled "In the name of the French people."The theory of the minister as judge was definitively abandoned by judicial decision of the Conseil d'État, in 1889, in Cadot.'

While the administrative courts had been established, the task was far from complete. Administrative justice and, therefore, administrative law had yet to be constructed. The central question lay in whether the law applicable to the Administration's activities ought to be separate from private law. Were administrative activities to obey a different rationale to that which governed relations between private individuals? The answer was given in a judgment that remains famous even today: the Blanco ${ }^{8}$ decision, according to which "the liability that may be incumbent on the State for damage caused to private individuals by actions performed by persons that it employs in the civil service, may not be governed by principles established in the Civil Code, with regard to relation between private individuals." This liability, according to the Tribunal des conflits (Court of Jurisdictional Conflict) "has its own special rules, which vary depending on the department's requirements and the need to reconcile the rights of the State with private rights..$^{19}$ Administrative case law therefore created, constructed, forged administrative law. In the main, the foundations of administrative law were developed and laid by the courts. Here lies the highly original nature of French administrative law. France, the nation of legal codification and written law, where one of the contributions made by the Napoleonic reforms was precisely to put an end to customary law (which, by definition, is unwritten), generated a law created by the courts. Be it the liability of public authorities, the rules applicable to the civil

5 Cf., Bigot Grégoire, Introduction historique au droit administratif depuis (Paris 1789, PUF 2002); Soleil Sylvain, Le modèle juridique français dans le monde: une ambition, une expansion (XVI-XIXe siècle) (Paris, Institut de recherche juridique de la Sorbonne, coll. Les voies du droit 2014).

6 Article 52 of the Constitution of the Year VIII (1799) provided that "under the direction of the consuls, a Council of State is responsible for drafting the draft laws and regulations of public administration, and resolve difficulties that arise in administrative matters."

7 CE, 13 December 1889, Cadot, Rec. 1148.

8 TC, 8 February 1873, Blanco, Rec. 61. And before : CE, 6 décembre 1855, Rec. 707.

9 Id. 
service, administrative contracts, the conditions of admissibility for judicial review applications, or even civil liberties, the Conseil d'État has often taken the initiative.

However, we must not think that the administrative courts were alone in undertaking this exercise in disciplinary construction. Jurisprudence supported it in its mission to summarise and create law. One thinks quite naturally of the epic quarelles between Léon Duguit and Maurice Hauriou, who each based administrative law on very different concepts. For Duguit, inspired by the sociology of Emile Durkheim, State legitimacy rests on the fact that law is the direct product of intersocial solidarity. Conversely, Hauriou based administrative law on public authority, where the latter is merely the expression of State power. These two divergent opinions are a deeper expression of a social choice and a concept of relations between those who govern and those who are governed. Despite this, the administrative courts, and particularly the Conseil d'État, have not always been officially partial to jurisprudence.

Administrative justice was therefore the founder of administrative law and the Conseil d'État has been one of the essential, if not unique, mechanisms. Admittedly, the conseils de Préfectures (prefecture councils) were established by the Law of 28 Pluviôse Year VIII, since replaced in 1953 by the administrative courts. The administrative courts of appeal were introduced in 1987. If the administrative branch is now complete, with three levels of appeal and a classic judicial organisation, the Conseil d'Etat continues to occupy a highly unusual place. More so even than the French Court of Cassation, it has much greater authority over the lower courts.

Despite these challenges, it must be said that the Conseil d'État has been able to imbue the Republic with a certain degree of stability. It has adapted and adjusted administrative law to legal developments and the globalisation of law. It has made administrative justice an institution that is essential to the operation of the state so much so that, despite the non-recognition of its existence in the 1958 French Constitution, the Constitutional Council granted it constitutional status in $1980^{10}$. The administrative courts and the administrative process therefore constitute, even now, a fundamental impulse point for developments in substantive and procedural administrative law - in short, for administrative justice.

\section{Judicial Organisation}

Unlike the singular which is sometimes used, the administrative court is by no means single and solitary. It consists of several types of courts and different categories of judges, but all give justice in the name of the State." In any case, their unity is

10 CC, No. 80-119 DC, 22 juillet 1980, Loi portant validation d'actes administratifs. Since 2008, 1958 Constitution refers to Conseil d'État (art. 39) ; cf., CE, 16 avril 2010, Association Alcaly et autres, req. No. 320667.

11 CE, Sect., 24 February 2004, Popin, Rec. 127. 
guaranteed by the Conseil d'Etat, which is placed at the top of the administrative justice hierarchy.

\subsection{The Administrative Courts}

In France, there are ordinary and specialist administrative courts.

\subsubsection{The Ordinary Administrative Courts}

The discussion will be limited to those courts that deal with the majority of cases, namely the Conseil d'État and the administrative courts and administrative courts of appeal.

\subsubsection{The Conseil d'État}

Established by the Constitution of the Year VIII, the Conseil is composed of some 300 people of which only $2 / 3$ are actually active. The others are usually lawyers, politicians or else occupy key posts in the French administration. The Conseil d'Etat is chaired in practice by the Vice President, the President being - formally - the Prime Minister. The latter, however, is never involved in the Conseil's work.

The Conseil d'État is composed of seven sections. Six of these are administrative, now known as consultative sections or chambres consultatives (interior; finances; public works; social; reports and studies; administration) while the seventh is the section du contentieux or litigation chamber. This division of labour into sections is a consequence of the Conseil's operational duality, being both the government's legal adviser and the supreme adminstrative court. As legal adviser, the Conseil $d^{\prime}$ État must be consulted to advise on bills or constitutional bills ${ }^{12}$. It must also must necessarily be consulted with regard to draft ordinances under Article 38 of the Constitution or for certain types of regulatory acts called décrets pris en Conseil d'État or, literally, "orders in Council of State" ${ }^{\prime \prime 3}$. However, it is purely a consultation and the Government is not bound to follow the position adopted by the Conseil d'État.

The Conseil d'Etat's judicial powers are governed by Article L. 111-1 of the Code de justice administrative (CJA - Administrative Justice Code) that "The Conseil d'Etat is the highest administrative court. It rules, without further possibility of appeal, on appeals on points of law lodged against judgments rendered at the last instance by the various administrative courts and tribunals and on cases that are referred to it as a court of first

12 The opinions of the Conseil d'État were not public. They could, however, be disclosed when significant public interest was involved. However, a draft constitutional law of 19 January 2015 (No. 2499) wished to make Conseil d'Etat opinions public. And in fact, without waiting for its adoption, the President of the Republic has wanted to make them public and include them in legislative dossiers since March 2015.

13 Since Loi organique No. 2011-333 du 29 mars 2011 relative au Défenseur des droits [Organic Law on the Defender of Rights] (art. 19), the Defender of Rights may also apply to the Conseil for a study on an issue that presents difficulties. This was the case for its opinion of 20 September 2013 concerning the application of the principle of religious neutrality in public services. 
instance or as an appeal court." First, the Conseil hears cases at first and last instance against national acts, disputes arising abroad or litigation for which the territorial jurisdiction covers both administrative courts. Such cases usually concern specific decrees, orders or regulatory acts of Ministers issued once the Conseil has given its opinion. Next, it may sit as a court of appeal, although this is now more of a residual activity. Such is the case of litigation concerning the calling of local and municipal elections or preliminary rulings. Lastly, and this is its main activity, the Conseil d'Etat is the final court of appeal for decisions handed down by the administrative courts of appeal, the specialist administrative courts and certain decisions of administrative tribunals for which the possibility of appeal has been ruled out. ${ }^{14}$ Lastly, it must be noted that the Conseil d'État may give an opinion (avis contentieux) on a new point of law which poses serious difficulty and is likely to be raised in many cases (art. L. 113-1 CJA). This procedure, introduced by the Law of 31 December 1987, allows trial judges to refer points of law to the Conseil d'État, and a dozen such decisions are handed down each year. ${ }^{15}$

\subsubsection{The Administrative Courts and Administrative Courts of Appeal}

Administrative courts were created by a Decree of 30 September 1953 (except the court at Strasbourg, founded in 1903) and replaced the conseils de préfectures. They are the ordinary administrative courts. Administrative Courts of Appeal were added to the judicial hierarchy by the Law of 31 December 1987 primarily for the purpose of unclogging a Conseil d'Etat overloaded with litigation. These two levels of jurisdiction operate on a collegial basis, even if the latter, like the judicial judge, tends to be undermined by the development of the single judge created to accelerate the processing of cases and according to a managerial logic, so much so that most decisions are taken by the single judge.

Like the Conseil d'Etat, administrative courts also have administrative powers. They may be consulted by the Prefect on points of law. ${ }^{16}$ The implications of this functional duality are surprising to say the least for administrative courts. For example, they have the power to give a taxpayer permission to replace a territorial public entity for the purposes of legal action. ${ }^{77}$

This abovementioned power offers the opportunity to highlight those criticisms that have punctuated the functional duality of administrative courts, in which the Conseil d'Etat is at the forefront. The duality now collides with that same separation. Is the combined role of court and legal advisor compatible both with the principle of

14 This is the case, for example, for decisions handed down in the context of référé-liberté proceedings.

15 For instance, CE, avis No. 315499 du 16 février 2009, Hoffman Glemane.

16 Laidié Yves, La fonction consultative des tribunaux administratifs, in Mercuzot Benoît (dir.), La loi du 28 pluviôse An VIII deux cents ans après: survivance ou pérennité? 249 (Paris, PUF 2000).

17 Similarly, the Law of 12 July 1983 conferred the appointment of some commissaires-enquêteurs to the presidents of administrative courts. These consultative functions are in practice rarely used. 
the separation of powers and the rules to ensure a fair trial as they arise in particular from Article 6 ECHR? In practice, it must be recognised that the Conseil d'Etat has always acted impartially. Only, to quite the English saying, justice must not only be done, it must also be seen to be done. Various cases have therefore indirectly raised the issue of the Conseil's objective impartiality before the ECtHR. ${ }^{18}$ It took the 2006 decision in Sacilor Lormines $v$ France for the ECtHR to consider that the functional duality did not per se violate the principle of judicial impartiality. ${ }^{19}$

\subsubsection{The Specialist Administrative Courts}

It is not possible to paint a full picture here, suffice it to say that the Cour des comptes (Court of Auditors) and regional audit chambers, the Commission nationale du droit d'asile (National Commission for the Right of Asylum), or the Conseil supérieur de la magistrature (High Council of the Judiciary) are, in some respects, ${ }^{20}$ specialist administrative courts. Professional associations have also been considered as specialist administrative courts although, in France, they are private entities and concern professions governed by private law. ${ }^{21}$ These professional associations, according to the logic of functional duality that governs the functioning of the administrative courts, also have non-judicial duties relating to the rules and organisation of the relevant profession.

The status as a court recognised to such bodies has not always made sense. For the purposes of characterising them as such, the administrative court may refer typically - to a body of evidence, examining the nature of the body, its functions, the measures it adopts and the status of its members. ${ }^{22}$ Be that as it may, from the time when the body in question is recognized as a court, all the general rules of trials will apply, whether it is respect for the rights of defence, the obligation to state reasons, independence and impartiality or an appeal before the Conseil d'Etat. These rules are often the general principles of law and are applicable, even in the absence of legislation, not to mention the binding framework set by Article 6 (1) ECHR. ${ }^{23}$

18 ECtHR, Procola v Luxembourg, Application No. 14570/89, 28 September 1995.

19 ECtHR, Sacilor Lormines v France, Application No. 65411/01, 9 November 2006, pts. 70 et s. In essence, the Court considered that "As in the case of the Council of State in the Netherlands, there is no cause to apply a particular constitutional law theory to the situation of the French Conseil d'Etat and to rule in abstracto on the organic and functional compatibility with Article $6 \S 1$ of the consultation of the Conseil $d^{\prime}$ tetat with regard to draft legislation and implementing decrees," adding that "the principle of the separation of powers is not decisive in the abstract."

20 It is an administrative court where it acts in its disciplinary capacity against judicial magistrates.

21 This is the case, for example, for the Conseil national des barreaux.

22 For a historical decision, see CE, ass. 7 February 1947, D'Aillières, Rec. 50; CE, ass., 12 juillet 1969, L'Etang, rec., 388.

23 Cf. below on fundamental principles. 


\subsection{Administrative Judges}

Even restricting the discussion to the ordinary administrative courts and excluding special administrative courts from our examination of the status of administrative judges, their lack of unity is no less striking. The founding distinction between the Conseil d'Etat and trial courts extends to the status of their members.

\subsubsection{Members of the Conseil d'État}

Members of the Conseil d'Etat are traditionally recruited through the Ecole nationale de l'administration (ENA - National School of Administration) - often described as the voie royale or royal road. Founded in the immediate aftermath of the Second World War, the ENA was designed to train high-level administration officials. It is therefore perfectly logical - but in a very French sense - that ENA graduates should enter the Conseil d'Etat and, having learned the fundamentals of being the perfect senior official, become judges. Admittedly, the quality of recruitment is not at issue and the adaptability of ENA graduates has always been outstanding. The fact remains that in a liberal democracy, the process is curious to say the least. On joining the Conseil d'Etat, young recruits acquire the status of auditeur (trainee literally, 'listener'); after a few years, they become maîtres des requêtes ('masters of requests') and, from the age of 45, they can aspire to become conseillers d'Etat ('state councilors'). These are customary career rules and make it possible to ensure the independence of members of the court and promote what is called, according to the enshrined phrase, an esprit de corps; an elegant expression which is, in practice, equivalent to corporatism. However, recruitment by ENA competitive exam is not the only path. It is possible to enter the venerable institution by the 'outer tower', i.e. by an appointment by the Conseil des ministres (Cabinet) $)^{24}$. Similarly, a new procedure was introduced in 2012 whereby an official may be seconded to the Conseil d'Etat as maître des requêtes en service extraordinaire ("master of requests in extraordinary service"). ${ }^{25}$ The first person to have benefited is a professor of public law who has since permanently joined the Conseil staff.

Members of the Conseil d'État are not legally considered as judges in the image of the judiciary. The CJA simply provides that "he status of the members of the Council of State is governed by this book and, provided they do not contradict it, by the statutory provisions governing the State public service" (Art. L. 131-1). The law governing public service therefore applies fully to administrative judges sitting at the Conseil d'État. This reluctance to be called judges is mainly due to the Conseil's functional duality.

24 The appointments are made, under Art. L. 133-8 CJA "on the basis of a proposal by the Vice-President of the Conseil d'État, who deliberates with the Section Presidents, after taking the opinion of the Superior Council of Administrative Tribunals and Administrative Courts of Appeal" so as to avoid any abuse. It concerns 1/3-1/4 of the appointments.

25 Article L. 133-9 CJA. 
Generally, the fear of a Vice President of the Conseil d'Etat, after the parliamentary elections and the formation of a new government, is a significant number of departures from the Conseil towards ministerial offices. This series of departures does nothing to help in managing caseloads and, in more practical terms, the smooth running of administrative justice.

\subsubsection{Judges of the Administrative Courts and Administrative Courts of Appeal}

Judges sitting at the administrative courts and administrative courts of appeal are known as Conseillers (Councillors). They belong to a single body, separate from the Conseil d'Etat. While in principle they too are recruited on graduating from the ENA, this process accounts for the recruitment of one-quarter of councillors. In reality the main recruitment method is based on an competitive examination, which became permanent in 2012.

Councillors have no status as magistrates within the meaning of Article 64 of the Constitution; this has been the case for some time. Despite their wish, the Conseil d'État has opposed granting them that status. ${ }^{26}$ However, what could not be obtained through case law was secured by law. The Law of 12 March 2012 added their status as magistrates to the $\mathrm{CJA} .{ }^{27}$ While no provision is made for tenure in the same way as sitting judges in the judicial courts, this omission does not raise difficulties from the viewpoint of the independence of administrative judges. The CJA provides that they cannot be given a new posting without their prior consent, which is equivalent to a form of tenure. ${ }^{28}$ Lastly, career management is ensured, slightly in the image of the Conseil supérieur de la magistrature (CSM - Supreme Council of the Judiciary) for the ordinary courts, by the Conseil supérieur des TA et CAA.

\section{The Jurisdiction of the Administrative Courts}

The scope of the jurisdiction of the administrative courts overlaps with the issue of the content of administrative law and the question of whether there is a criterion of administrative law. The administrative courts have built their own jurisdiction whilst developing their law. Today, their jurisdiction is no longer in any doubt and even enjoys a degree of protection.

\subsection{The Principle of Separation}

The separation of the judicial and administrative courts generally poses few if any difficulties in terms of litigation. Nevertheless, this question has long stirred up

\footnotetext{
26 CE, Ass., 2 February 1962, Beausse, Rec. 82.

27 Art. L. 221-1 CJA.

28 Art. L. 231-3 CJA.
} 
jurisprudence insofar as it was closely related to the disciplinary area of administrative law. The adage "la compétence suit le fond" ("the jurisdiction follows the substance") presupposes knowledge of the applicable law (civil or administrative) to determine the competent court (civil or administrative). This reasoning is also contained in the Blanco decision. ${ }^{29}$ It is also that of the jurisprudential disputation between Duguit, and especially Gaston Jèze, and Hauriou. For Duguit - Jèze, only activities and acts with a public service purpose required public law rules and, therefore, the jurisdiction of administrative courts. For Hauriou, only the activities and actions expressing public authority required public law rules and therefore the jurisdiction of administrative courts. Without being able to examine every development in case law, it can be said that today the two are complementary, so much so that it no longer any criterion for the jurisdiction of the administrative courts other but grounds of jurisdiction. However, this is not because the jurisdiction of administrative courts is of common law when the administration is concerned that the judicial courts are systematically disregarded. Exceptions remain.

\subsubsection{Grounds of Jurisdiction}

If one were to give an especially brief summary, it would appear that two criteria serve in understanding the jurisdiction of the administrative courts: an organic criterion and a material criterion. The organic criterion concerns the public or private nature of the person involved in the dispute. The material criterion concerns either the nature of the activity (is it a public service?), ${ }_{3}^{30}$ or the nature of the act adopted (did this involve the exercise of public powers?).. ${ }^{31}$ Despite some uncertainties in case law, the public service criterion remains the benchmark. However, a distinction was made between services publics administratifs (SPA - administrative public services), which fall largely within the remit of the administrative court; and service public industriel et commercial (SPIC - industrial and commercial public service), which is predominantly subject to the jurisdiction of the ordinary courts.

Lastly, it should be noted that, even if it is true that in most cases the adage "the jurisdiction follows the substance" is well and truly respected, it is not systematically so. For example, the administrative court applies competition law, which is primarily composed of private law rules. It may also apply criminal law to the administration, not to condemn it as a legal person, but to annul an act that would otherwise place

29 Cf., above.

30 TC, 28 March 1955, Effimief, Rec. 617 ; CE, Sect. 20 avril 1956, Bertin et Grimouard, Rec. 167 et 168.

31 CE, 31 July1912, Société des granits porphyroïdes des Vosges, Rec. 909. The CC also considered, in its decision of 23 January 1987, Conseil de la concurrence, that the cancellation and reformation of "decisions taken in the exercise of public authority" fell within the jurisdiction of the administrative courts. The articulation of these two criteria is not always simple: CE Sect., 28 June 1963, Narcy, Rec. 401; CE, Sect., 22 February 2007, APREI, Rec. 92. 
the public official in a position of infringing criminal law provisions. ${ }^{32}$ Conversely, the judicial court have jurisdiction to hear cases involving the liability of the judicial police and applies general rules of administrative liability. ${ }^{33}$

\subsubsection{Exceptions to Jurisdiction}

As mentioned above, the judicial courts have jurisdiction in principle to hear disputes between a SPIC and a user. However, beyond this scenario - and many other special cases ${ }^{34}$ - there are two situations in which the ordinary courts will have jurisdiction even though logic dictates that it should fall to the administrative courts. Firstly, the judicial courts have jurisdiction for litigation involving judicial justice. This situation is explained by the principle of the separation of judicial and administrative courts. Owing to the fact that justice is a public service, judicial jurisdiction is not absolute. This is a thorny question to day the least as, whilst remaining a public service, the constitutional independence of the judiciary must not lead to a subordination of the judicial courts with regard to the administrative courts. The separation of powers was set down long ago by a decision of the Tribunal des conflicts (Court of Jurisdictional Conflict) in Préfet de Guyane, ${ }^{35}$ according to which the judicial courts have jurisdiction for all that relates to the operation of the judicial public service; the administrative courts have jurisdiction for matters relating to the organisation of the judicial public service. The difference is sometimes tenuous. ${ }^{36}$ The trend, however, is to have a broad view of the jurisdiction of the administrative courts and the decisions that are considered as inseparable from the organisation of the public service that is the justice system. Thus, the State's liability may be incurred before the administrative courts for the activities of the judicial police related to the judicial public service. ${ }^{37}$ Purely judicial acts continue to fall within the remit of the judicial courts, as is the case of the appointment of assize court presidents by the President of the Court of Appeal, the decisions of legal aid services or acts for

32 CE, Ass. 6 December 1966, Société Lambda, Rec. 466.

33 Cass. Civ. 23 November 1956, Giry, Bull. II. 407. For a recent application concerning police controls, cf., Cour d'appel de Paris, 24 June 2015, No. 13/24277.

34 Mention should be made of those cases in which the criminal court has jurisdiction to assess the lawfulness of an administrative act without being able to annul it. Similarly, the judicial courts have jurisdiction to assess the damage suffered as a consequence of compulsory treatment ordered by the administration which takes place without consent.

35 TC, 27 November 1952, Préfet de la Guyane, Rec. 642; CE, Ass., 17 December 1953, Falco et Vidaillac, Rec. 175.

36 Case law gives the administrative court the exact jurisdiction that it considers detachable from the enforcement of judgments, such as the amnesty decrees with the decision in Dalmas de Polignac of 22 November 1953. However, the decrees declaring clemency for a convicted person fall outside the jurisdiction of the administrative court, being the exclusive power of the Head of State.

37 TC, 9 March 2015, Consorts C-R, req. No. 3990. 
enforcing judgments. As regards the decisions of enforcement judges, these may fall either to the administrative or judicial courts depending on their content. ${ }^{38}$

Secondly, the judicial courts have jurisdiction for disputes involving the violation of certain fundamental rights. These are exceptions that fall to the judicial courts as guarantors of individual freedom and the right of property. They concern assault $t^{39}$ and illegal expropriation. ${ }^{40}$ Assault, traditionally defined as an act manifestly not linked to the administration, ${ }^{41}$ est an infringement of the right of ownership or to individual freedom. ${ }^{42} \ln$ Bergoend ${ }^{43}$ the Tribunal des conflits gave a stricter definition of the scope in which only the total extinction of property rights may constitute a violation of property rights and not a mere infringement. Illegal expropriation is there to punish violations to real property. As it did for assault, the Tribunal has restricted the scope of illegal expropriation. ${ }^{44}$ Again, only definitive dispossession constitutes an illegal expropriation. Temporary dispossession therefore falls within the remit of the administrative courts. The establishment of référé-liberté proceedings (essentially an application for the protection of fundamental freedoms) by the Law of 30 June 2000, however, has resulted in a decline in the value and utility of such remedies. ${ }^{45}$

\subsection{Protecting the Separation}

Aside from the constitutionalisation of the administrative courts by the Constitutional Council, ${ }^{46}$ the Tribunal des conflits - composed of an equal number of members from the Conseil d'État and the Court of Cassation - is tasked with preserving jurisdictional duality. It must rule on conflicts of jurisdiction between ordinary courts and administrative courts. ${ }^{47}$ It has also just undergone significant

38 A temporary absence granted to a prisoner is an administrative decision; however, decisions concerning the duration or nature of sentences fall to the judicial courts.

39 TC, 8 April 1935, Action Française, Rec. 1226.

40 TC, 17 March1949 Société Hôtel du vieux Beffroi, Rec. 592.

41 CE, 18 November 1949, Carlier, Rec. 490.

42 TC, 25 January 1988, Fondation Cousteau, Rec. 484.

43 TC, 17 June 2013, Bergoend C/ ERDF, req. No. 3911.

44 TC, 9 December 2013, Panizzon, req. No. 3931.

45 Under the Law of 30 June 2000, the référé-liberté provides that "receiving a request in this sense justified by urgency, the judge may order any measures necessary to safeguard a fundamental freedom which a public entity or a private entity responsible for the management of a public service may, in the exercise of its powers, have seriously and manifestly infringed unlawfully. The judge shall decide within fortyeight hours."

46 CC, 23 janvier 1987, Conseil de la concurrence (préc.).

47 This was provided by the Constitution of the Second Republic. It was then abolished and reinstated by the Law of 24 May 1872. 
reform. ${ }^{48}$ Aside from those rare cases in which it rules on substantive aspects, ${ }^{49}$ the greater part of the Tribunal's work lies in resolving conflicts of jurisdiction between ordinary courts and administrative courts. It can hear cases of negative or positive conflict. There are negative conflicts when neither court considers that it has jurisdiction to hear the case brought before it. There are positive conflicts when both courts consider that they have jurisdiction. In the latter situation, further to proceedings, the Prefect will raise the conflict of jurisdiction and apply to the Tribunal des conflits. Where there is a negative conflict, the decree of 25 July 1960 provides that, if a court declines jurisdiction in a decision that then becomes final, the second court, if it too considers that it does not have jurisdiction, shall refer the matter to the Tribunal. The disadvantage of this procedure is that the applicant must previously have applied to both courts. That is why there are other referral methods. The Conseil $d^{\prime}$ État and the Court of Cassation can thus apply to the Tribunal when they consider that a serious question of jurisdiction has arisen in a case before them. The difficulty is that this referral is for supreme courts, which means that the applicant has passed all stages of proceedings before both courts, and therefore they had the financial means to 'afford'such proceedings. This is why the 2015 reform opened the referral for serious jurisdiction issues to all lower courts.

We will conclude by saying that there is one last technique for protecting the separation of the different types of court: referrals for preliminary rulings. This is not the same as referrals made by national courts to the European Court of Justice. It is a referral for a preliminary ruling, made by the judicial court to the administrative court where the former court is required to rule first on a question of administrative law. ${ }^{50}$ The judicial court cannot in fact assess the lawfulness of an administrative act and cannot interpret an individual administrative act the meaning of which is not clear. ${ }^{51}$ The preliminary ruling given by the administrative court is binding on the judicial court ruling in the main proceedings. It should be noted that adjustments have been made to this procedure by case law, particularly where EU law is at issue, ${ }^{52}$ but also owing to the Law of 16 February 2015.

Citizens can challenge the lawfulness of acts adopted by the administration or assert rights against the latter through various remedies. The current classification of appeals available in the administrative courts comes history. It was forged by the courts and the systematisation of jurisprudence. Two main classifications have been put forward.

48 Law of 16 February 2015 and Decree No. 2015-233 of 27 February 2015.The presidency of the Garde des sceaux has been abolished.

49 It is not particularly active, giving only some fifty decisions every year.

50 TC, 16 June 1923, Septfonds, Rec. 498.

51 It may, however, interpret a regulatory administrative act.

52 TC, 17 October 2011, SCEA du Chéneau, Rec. 498; TC, 12 December 2011, Société Green Yellow, Rec. 592. 
The first classification is formal. Developed in the nineteenth century,' it is derived from the synthesis of the work of two state councillors, Leon Aucoc ${ }^{53}$ and Edouard Laferrière, ${ }^{54}$ who distinguished different types of litigation on the basis of the powers recognised to the court when considering the merits of the claim. They identified four types of litigation: actions brought on grounds of ultra vires, in which the court may only annul the challenged decision; full litigation or (the terms are synonymous) full jurisdiction litigation, in which the judge can reform the administrative act; litigation on interpretation or validity, through a referral for a preliminary ruling made the judicial court to the administrative court, in which the latter rules on the lawfulness of an act without settling the dispute between the parties; and enforcement litigation, in which the court can order a citizen to repair the damage caused to the public domain.

The second classification is material. It results from the work of Léon Duguit who, in the late 19th century, established the distinction between different types of litigation on the basis of the nature of the issue put to the court. ${ }^{55}$ This criterion serves to identify objective litigation, which concerns the lawfulness of an act (such as appeals brought on grounds of ultra vires, actions involving an assessment of lawfulness, or certain other cases such as tax or electoral disputes); and subjective litigation, in which the court must rule on the existence of individual rights which the applicant derives from a single situation, such as contractual or liability disputes.

These classifications, the primary value of which is educational, are not contradictory and may be combined. In practice the formal classification is the most important, however, because it helps to understand the different facets of the role played by the administrative court. Depending on the case concerned, the legal rules applicable to the appeal will not be the same. Within this classification, the appeal on grounds of ultra vires and full remedy actions hold a special place because they are predominant in the jurisdictional activity of the administrative courts. This distinction has evolved over time. To this must be added litigation concerning the implementation of the question prioritaire de constitutionnalité (priority preliminary ruling on constitutionality), to challenge the constitutionality of a law already in force.

\section{The Remedies Available before the Administrative Court}

Citizens can challenge the lawfulness of acts adopted by the administration or assert rights against the latter through various remedies. The current classification

53 Aucoc Léon, Conférences sur l'administration et le droit administratif 361 (Dunod, 1st éd., tome 1, Paris 1869).

54 Laferrière Édouard, Traité de la juridiction administrative et des recours contentieux 15 (BergerLevrault, 2 d éd., tome 1, Paris 1896).

55 Duguit Léon, Traité de droit constitutionnel 458 (de Boccard, 3d éd., tome 2, Paris 1928). 
of appeals available in the administrative courts comes history. It was forged by the courts and the systematisation of jurisprudence. Two main classifications have been put forward.

The first classification is formal. Developed in the nineteenth century, it is derived from the synthesis of the work of two state councillors, Leon Aucoc ${ }^{56}$ and Edouard Laferrière, ${ }^{57}$ who distinguished different types of litigation on the basis of the powers recognised to the court when considering the merits of the claim. They identified four types of litigation: actions brought on grounds of ultra vires, in which the court may only annul the challenged decision; full litigation or (the terms are synonymous) full jurisdiction litigation, in which the judge can reform the administrative act; litigation on interpretation or validity, through a referral for a preliminary ruling made the judicial court to the administrative court, in which the latter rules on the lawfulness of an act without settling the dispute between the parties; and enforcement litigation, in which the court can order a citizen to repair the damage caused to the public domain.

The second classification is material. It results from the work of Léon Duguit who, in the late 19th century, established the distinction between different types of litigation on the basis of the nature of the issue put to the court. ${ }^{58}$ This criterion serves to identify objective litigation, which concerns the lawfulness of an act (such as appeals brought on grounds of ultra vires, actions involving an assessment of lawfulness, or certain other cases such as tax or electoral disputes); and subjective litigation, in which the court must rule on the existence of individual rights which the applicant derives from a single situation, such as contractual or liability disputes.

These classifications, the primary value of which is educational, are not contradictory and may be combined. In practice the formal classification is the most important, however, because it helps to understand the different facets of the role played by the administrative court. Depending on the case concerned, the legal rules applicable to the appeal will not be the same. Within this classification, the appeal on grounds of ultra vires and full remedy actions hold a special place because they are predominant in the jurisdictional activity of the administrative courts. This distinction has evolved over time. To this must be added litigation concerning the implementation of the question prioritaire de constitutionnalité (priority preliminary ruling on constitutionality), to challenge the constitutionality of a law already in force.

56 Aucoc Léon, Conférences sur l'administration et le droit administratif 361 (Dunod, 1st éd., tome 1, Paris 1869).

57 Laferrière Édouard, Traité de la juridiction administrative et des recours contentieux 15 (BergerLevrault, 2st éd., tome 1, Paris 1896).

58 Duguit Léon, Traité de droit constitutionnel 458 (de Boccard, 3d éd., tome 2, Paris 1928). 


\subsection{The Distinction between Actions on Grounds of Ultra Vires and Full Remedy Proceedings}

\subsubsection{Actions on Grounds of Ultra Vires}

The action on grounds of ultra vires was created and perfected by the Conseil $d^{\prime}$ Etat. 'Trial in action, ${ }^{\prime 59}$ in the words of Edouard Laferrière, the action on grounds of ultra vires is an instrument of French political liberalism developed from the last third of the nineteenth century. It has long appeared as "the most effective weapon, the most practical, most economical that exists in the world to defend individual freedoms..$^{150}$ Open against any administrative act, even in the absence of legislation, ${ }^{61}$ this action allows any citizen to ensure that administrative action is lawful. This explains why, in assessing the lawfulness of the act, the court considers the situation of law and fact existing at the date the administration adopted its decision. The decision to annul, having the authority of res judicata, is binding on all. In addition, litigants are under no obligation to engage a lawyer; their interest in bringing proceedings is assessed broadly, without having to prove the infringement of a right, and in the event of withdrawal it is possible to do so under relatively flexible conditions.

The court's powers have long been restricted to the annulment of the act at issue, which occasionally results in the decision having only limited effects for litigants. This is not the case in the context of full remedy proceedings.

\subsubsection{Full Remedy Proceedings}

Full remedy proceedings, unlike actions on grounds of ultra vires, are not homogeneous. There are at least two kinds of full remedy proceedings. Firstly, the court can hear subjective full remedy proceedings, the purpose of which, as the name suggests, is to have an individual right recognised. It mainly concerns contractual disputes and litigation involving administrative liability. On the other hand, there are objective full remedy proceedings, which admittedly concern the lawfulness of an act but in which the court's powers are not limited to annulment (cases concerning taxation, penalties, listed buildings, etc.).

Different full remedy proceedings are designed to secure the restoration of a legal situation. The court therefore rules in light of the situation of law and fact existing on the day when it hands down its decision; it holds a wide range of powers allowing it to alter the decision at issue or to substitute its judgment for that of the administration.

59 Laferrière Édouard, Traité de la juridiction administrative et des recours contentieux 561, Id.

60 Jèze Gaston, Les libertés individuelles 162-186 (Annuaire de I'Institut International de droit public, PUF, Paris 1929).

61 CE, ass., 17 February 1950, ministre de l'agriculture c/ Dame Lamotte, Rec. at 110. 


\subsection{Developments in the Distinction}

Since the 1970s, the administrative courts, especially under the influence of European laws, have searched for a better guarantee of citizens' rights and, concomitantly, the increased effectiveness of legal actions. These factors have changed for the action on grounds of ultra vires and overhauled full remedy proceedings.

\subsubsection{The New Action on Grounds of Ultra Vires}

The major deficiency in the action on grounds of ultra vires was linked to the inability to fully resolve the applicant's situation when bringing the action. Annulment could sometimes not be sufficient, specifically if the applicant sought to challenge a refusal ${ }^{62}$ or, on the contrary, a decision that was excessive in light of the general interest. The court's powers were therefore enhanced. On the one hand, in order to improve the effectiveness of this remedy for citizens, the Law of 8 February $1995^{63}$ gave the courts a power of injunction with regard to the administration, subject to a fine where applicable. The courts may therefore indicate to the administration all the consequences to be drawn from the annulment decision. Furthermore, to better reflect the general interest, the Conseil $d^{\prime} E$ tat has, in its case law, granted new powers to courts hearing such cases: they can now avoid the annulment of a decision which may have a different legal basis (change of legal basis or grounds) ${ }^{64}$ or temper the effects of their decisions over time by derogating from the principle of retroactivity.

\subsubsection{Overhauling Full Remedy Proceedings}

Full remedy proceedings have been overhauled. On the one hand, owing to the court's powers, the scope of full remedy proceedings has increased. The legislature has opened this remedy against various sanctions, including those adopted by regulatory authorities. ${ }^{65}$ Equally, the Conseil d'Etat switched some areas, initially falling within the remit of actions on grounds of ultra vires, to that of full remedy proceedings, such as cases involving administrative penalties ${ }^{66}$ or points on driving licences ${ }^{67}$ On the other hand, and in parallel, the various powers of courts hearing full

62 The applicant did not obtain the decision expected from the administration, merely the annulment of the refusal.

63 et administrative [Law No. 95-125 of 8 February 1995 on the organisation of the courts and on civil, criminal and administrative procedure], JORF du 9 février 1995, at 2175.

64

65

66

67

CE, 6 Feb. 2004, Hallal, Rec. 2004, at 48.

Article L. 311-4 CJA.

CE, ass., 16 Feb. 2009, Société Atom, Rec., at 25.

CE, avis, 9 July 2010, Berthaud, Rec., at 287. 
remedy proceedings have also been extended and refined. The administrative courts can now ensure a better balance of interests between lawfulness and legal certainty for the benefit of the latter objective. Thus, in opening full remedy proceedings to third parties in order to challenge administrative contracts, the Conseil d'Etat also stated that the court hearing the case may decide on the continuation of the contract; invite the parties to regularise or amend the contract; order the termination or cancellation of the contract, with deferred effect where applicable; or compensate a party. ${ }^{68}$

These developments tend to blur the distinction between actions brought on grounds of ultra vires and full remedy proceedings, as the courts hearing ultra vires actions have acquired a kind of power of reform. ${ }^{69}$ Only a few procedural differences remain, such as the date chosen by the court in order to assess the lawfulness of the contested decision.

\subsection{The Emergence of the Question Prioritaire de Constitutionnalité}

Very belatedly compared to other European states, France instituted a process for the a posteriori constitutional review of laws. The Constitutional Law of 23 July $2008^{70}$ introduced the specific mechanism of the question prioritaire de constitutionnalité, which allows a litigant to apply to the Constitutional Council for the repeal of laws that infringe rights and freedoms guaranteed by the Constitution. Under the terms of Article 61-1 of the Constitution, the question prioritaire de constitutionnalite involves the lower courts, administrative or judicial, which must, during ongoing proceeding, ensure in particular that the issue is not devoid of merit and that its resolution will allow judgment to be given in the case between the parties. If this is so, the matter is forwarded to the Conseil d'Etat (for the administrative courts) or the Court of Cassation (for the judicial courts), both of which act as filters. Neither can declare a law contrary to the Constitution. Their only role is to ensure that the matter is sufficiently serious. If so, the matter is forwarded to the Constitutional Council which will decide on the constitutionality of the law, declaring it either contrary to or consistent with the Constitution. If the answer is negative, the matter will be dismissed by the Conseil d'Etat or Court of Cassation and the case will resume its course; this is tantamount to the latter courts declaring that the law is consistent with the Constitution

68

CE, ass., 4 Apr. 2014, Département du Tarn-et-Garonne, Rec. at 70.

69 Melleray Fabrice, La distinction des contentieux est-elle un archaïsme? 30-34 JCPA 1296 (2005).

70 Loi constitutionnelle No. 2008-724 du 23 juillet 2008 de modernisation des institutions de la Ve République [Constitutional Law No. 2008-724 of 23 July 2008 modernising the institutions of the Fifth Republic], JORF du 24 juillet 2008, at 11890 


\section{Fundamental Principles Applicable to Administrative Proceedings}

The concept of 'basic principles' applicable to proceedings before the administrative courts is not an enshrined term. Case law has mentioned "general principles that govern the operation of administrative courts" ${ }^{\prime \prime 1}$ and the doctrine of 'general principles' in relation with the theory of general principles of law ${ }^{72}$ or even 'guiding principles'..$^{\prime 3}$ It took the CJA to draw out the legal consequences by introducing what was dubbed a "decalogue" within its opening provisions. Articles L.1 to L.11 actually set down the fundamental principles of administrative proceedings that govern the proceedings as a whole. They are diverse and among them we can distinguish the principles governing the organisation of justice $(A)$ and the principles relating to the fairness of the proceedings (B).

\subsection{Principles Governing the Organisation of Justice}

These are structural principles that do not necessarily appear in the 'Decalogue' but are implied by the existence of administrative justice and the very idea of justice. We can count at least three: independence, impartiality, and collegiality.

The principle of judicial independence must be reaffirmed with greater force with regard to administrative justice. It is well known how difficult it is to gain greater independence from and we cannot overstate that "to judge the administration is still to administer." That independence was reiterated by the Conseil d'Etat and implies, on the one hand, that a court does not have to take instructions from any authority whatsoever ${ }^{74}$ and, on the other hand, that a member of an administrative court cannot participate in judging an act where they have taken part in elaborating that same act. ${ }^{75}$ Often the principle of independence has an organic content and essentially extends to issues of an organisational nature of the court or the work of the court. It is however not always easy to distinguish the principle of independence from its corollary, the principle of impartiality. Indeed, "ignorance of the requirement of independence mechanically leads to a violation of the principle of impartiality but the reverse is not

71 CE, Ass., 28 June 2002, Magiera, Rec. 248.

72 Chaudet Jean-Pierre, Les principes généraux de la procédure administrative contentieuse (Paris, LGDJ 1967).

73 Guyomar Mattias et Seiller Bertrand, Contentieux administratif 332 (Dalloz, coll. HyperCours, Paris 2014) ; Gonod Pascale et alii (dir.), Traité de droit administratif 549 (tome 2, Dalloz, Paris 2011).

74 CE, Ass. 6 December 2000, Trognon, Rec. 427 ; CC, 20 February 2003 (No. 2003- 466 DC); CC, 28 December 2006 (No. 2006-545 DC)

75 CE, 26 May 2010, Marc-Antoine, req. No. 309503. 
true. ${ }^{176}$ The fact remains that in one case as in the other, these requirements weigh on both the court as an institution and the members of courts.

While it is not new in itself, the principle of impartiality has undergone a significant development in terms of case law, primarily related to the case law of the ECtHR. Impartiality is generally split into two categories: objective and subjective impartiality. The latter focuses on the person of the judge. Thus a relationship with a party or links to an earlier case will call that impartiality into question. If it is ever proven, a party may request the disqualification of the judge considered impartial only if there are serious grounds to do so. In the most serious cases, and if the impartiality concerns all of a court, use can be made of legitimate suspicion proceedings." Objective impartiality has led to substantial changes in administrative proceedings. This form of impartiality consists in criticising the organisation of the court and proceedings which can lead to - or suggest - a decision which might not appear to be fully impartial. It has been said that the structural duality of the Conseil $d^{\prime} E$ tat has been indirectly challenged before the ECtHR but that the latter has not considered it, even in principle, as contrary to the requirements of Article 6 (1) ECHR. ${ }^{78}$ However, the position of the former government commissioner has not benefited from the clemency of the ECtHR. It is worth noting that the government commissioner was responsible for submitting, in the form of reasoned submissions, the solution to the legal problem raised by the litigation, a bit like an Advocate General within the European Court of Justice. The ECtHR was shaken by Kress V/France in which the Court held that the presence of the government commissioner at the deliberations was in violation of the requirement of impartiality under Article 6 (1) ECHR. ${ }^{79}$ The Court added, as part of the grounds of its judgment, the fact that the commissioner spoke at the end of the hearing without the parties being able to reply ${ }^{80}$ French jurisprudence voiced its deep disagreement with the ECtHR by remarking that the latter had given way to the tyranny of appearances. The Decrees of 1 August 2006 and 7 January 2009 nevertheless drew the necessary consequences and amended French procedure in line with the recommendations of the ECtHR. The most recent Decree took the opportunity to change the name of the institution and remove any risk of confusion on the part of litigants; it is now known as the rapporteur public. ${ }^{81}$

76 Guyomar Mattias et Seiller Bertrand, Contentieux administratif 722, cited above.

77 CE, 6 October 1999, Pinault, req. No. 200386. This option is still possible, even in the absence of any law, owing to general rules of procedure.

78 Cf., above

79 ECtHR, Application No. 39594/98, 7 June 2001.

80 ECtHR, Martinie c/ France, Application No. 58675/00, 12 April 2006.

81 Art. L.7 CJA provides that "A member of the court, appointed to act as consultant judge, presents his or her opinion, in public and with total independence, on the issues that must be decided by the court, that arise from the applications or appeals, and on the possible solutions." 
The principle of collegiality is also part of the guiding principles of administrative proceedings. It features explicitly in the CJA, at Art. L. 3. Collegiality is considered rightly - as a guarantee of fair and impartial justice. It carries with it the concept of peer review and is one of the keys to high-quality justice. It must be recognized, however, that the scope of the principle of collegiality is increasingly limited. Sacrificed on the altar of efficiency and budget savings, it was necessary to remove it from certain proceedings requiring a decision from the single judge. Moreover, the Constitutional Council found that the single-judge proceedings were not in themselves contrary to the Constitution; ${ }^{82}$ it could scarcely do otherwise given the proliferation of such proceedings, be it in the judicial or the administrative sphere ... It should be noted that the ECtHR also rules as a single judge - and increasingly so. Many areas now fall within the remit of the single judge procedure. This is so for vases involving social benefits, pensions, the disclosure of administrative records, local taxes, refusals to use the police to execute a court decision or disputes relating to unsafe buildings. This is also the case for referrals.

\subsection{Principles Relating to the Fairness of Proceedings}

The fairness of proceedings before the administrative court is guaranteed by a number of general principles or rules of the trial. These include the principle of equality of arms, the adversarial principle and, in general, the reliability of proceedings.

The concept of equality of arms is little used in French positive law. Jurisprudence is quicker to resort to it, probably given the influence of the ECtHR, which has held that the principle of equality of arms "is one aspect of the broader concept of a fair trial before an independent and impartial tribunal."133 Under ECHR law, the principle of equality of arms has mostly been applied in law enforcement, and criminal law in particular. In administrative proceedings, the idea that innervates this principle consists in ensuring that the frequent imbalance between the parties does not lead to an unbalanced treatment of the case where the administration would be preferred. The inquisitorial trial before an administrative judge is the first guarantee of the equality of arms. However, the adversarial principle naturally remains central. It is a general principle of law ${ }^{84}$ and is the essence of equality of arms, of the rights of defence and, more generally, the reliability of the trial.

The adversarial principle, while being the essence of judicial proceedings, is not limited to it. Indeed we know that this principle is also applied before independent

82 CC, 14 October 2010, QPC No. 2010-54, USMA.

83 ECtHR, Delcourt, Application No. 2689/65, 17 January 1970, pt. 27

84 CE, 16 January 1976, Gate dubosc, Rec. 39 ; CE, Ass. 12 October 1979, Rassemblement des nouveaux avocats de France, Rec. 370. 
administrative authorities owing to the application of Article $6(1) .^{85}$ But it is obviously before the court that this principle has been acclaimed. It applies in the context of preliminary proceedings, with the disclosure of the case file to the official subject to disciplinary sanctions, for example. ${ }^{86}$ At the litigation stage, it results in the obligation to submit briefs to the parties and the court shall transmit them any item of additional information received. If information filed by a party is subject to confidentiality, and in particular medical confidentiality, the court will not consider evidence of which the other party has no knowledge. ${ }^{87}$ This naturally raises difficulties as regards the war on terror. ${ }^{88}$ Lastly, this also constituted grounds for France's condemnation by the ECtHR in respect of the inability of the parties to know the meaning of the rapporteur public's conclusions, which justified the adoption of the Decree of 7 January $2009 .{ }^{89}$ The adversarial principle is subject to restrictions in the context of emergency proceedings. ${ }^{90}$

Fair judicial proceedings cannot be so without compliance with publicity and, more broadly, transparency requirements. The idea of transparency is at the heart of the very idea of justice. Here we see the rationale of the publicity of hearings, which features under Article L. 6. In other words, not everything need be made public but, if a hearing should be held, the latter will necessarily be public ${ }^{91}$ and notified to the parties. The public nature of hearings is therefore, according to the Conseil d'État, a means for ensuring the respect of the rights of defence..$^{22}$ Therefore, and more generally, it is the reliability of the trial and transparency of the proceedings that guarantee the fairness of those proceedings and, therefore, the right to an effective judicial remedy. The principle of reliability, which has not been formalised per se in the sphere of proceedings before administrative courts, is guaranteed in practice by compliance, in particular, with the rules mentioned above and others, such as the fairness of legal argument, the requirement that reasons be given for a judgment (Art. L.9 CJA) ${ }^{93}$, or

85 CE, 3 December 1999, Didier, Rec. at 399 ; Cass., 5 February 1999, COB c/ Oury, No. 97-16.441.

86 Cf., Article 19 of the Law of 13 July 1983 concerning the rights and obligations of civil servants.

87 CE, Ass., 6 November 2002, Moon Sun Myung, Rec. 380.

88 This is also because of this that the Tribunal's Rules of Procedure of the European Union was revised in 2015 and in particular Article 105 on the processing of information or documents relating to the Union's security or that one or more of its Member States or the conduct of their international relations.

89 On this point, see above.

90 In certain cases the judge can do without, especially "When the application is not urgent or if it is clear, in the light of the application, that it does not fall within the jurisdiction of the administrative court, that it is inadmissible or unfounded" (art. L. 522-3 CJA). Similarly, cf., Art. L.5: "Certain requirements flow from the fact that both parties are represented; if the case is urgent, these former requirements will be adapted to those of the urgent situation."

91 Thus the Law of 29 December 1983 belatedly abolished in camera hearings for taxation cases.

92 CE, Sect. 26 July 1978, Auguste, Rec. 336.

93 CE, Sect. 5 December 1924, Platon, Rec. 270. 
even the obligation to give judgment within a reasonable timeframe. Ultimately, this requirement of reliability and transparency embodies the very concept of justice, according to which justice must not be an abstraction, but rather a tangible reality.

\section{A Comparative Approach}

Administrative justice, as it exists in France, is found in other European countries, with a more or less pronounced degree of similarity. Also, included in a globalised legal space, administrative justice is now largely influenced by European laws, be it the law of the EU or that of the European Convention on Human Rights, or even the national administrative laws of other European states.

\subsection{The Influence of French Administrative Justice in Europe}

Administrative justice is not a French exception, although it is sometimes presented as such. It is widely present elsewhere in the various European states. Nevertheless, France has been a pioneer in rapidly developing a complete model of administrative justice, ${ }^{94}$ characterised by full judicial dualism, from base to summit, and the creation of the Conseil d'Etat, the supreme administrative court which has the 'particularity' of combining judicial and advisory functions. ${ }^{95}$ The advanced nature of French administrative justice, in the early 19th century,' has therefore produced a 'remarkable export product.96

Initially, the duplication of the French model was largely restricted for the most part to countries under French rule following the Napoleonic wars. From this point of view, the Conseil d'Etat, the centerpiece of the Napoleonic regime, is traditionally presented as'one of the best' export items "of the Napoleonic administration in Europe. ${ }^{197}$ Under the influence of Napoleon, many'satellite Conseils d'Etat ${ }^{198}$ emerged in annexed countries. This was the case, for example, in Italy in $1805^{99}$ or Spain in 1808 . These states, on regaining their independence, sometimes returned to creating their own

94 Fromont Michel, La justice administrative en Europe. Convergences 197-208 (Mélanges René Chapus. Droit administratif, Montchrestien, Paris 1992).

95 See above, I.

96 Gaudemet Yves, L'exportation du droit administratiffrançais. Brèves remarques en forme de paradoxe 432 (Mélanges Philippe Ardant. Droit et politique à la croisée des cultures, LGDJ, Paris 1999).

97 Fougère Louis, (dir.), Le Conseil d'Etat : son histoire à travers les documents d'époque 157 (Éditions du Centre national de la recherche scientifique, Paris 1974).

98 Id.

99 Bellagamba Ugo, Le contentieux administratif en Italie au XIX siècle: modèles et pratique 247-262 (J. Hautebert et S. Soleil (dir), Modèles français, enjeux politiques et élaboration des grands textes de procédure en Europe, Editions juridiques et techniques, tome 1, Paris 2007). 
administrative justice or, conversely, decided to retain the legal organisation whilst adapting it to their legal culture.

Today, administrative justice continues to occupy a significant place in Europe: 16 of the 28 Member States of the European Union have an administrative justice system..$^{100}$ The French system is however not reproduced identically and jurisdictional duality does not necessarily imply the presence of a Conseil $d^{\prime} E t a t$. There are four categories. ${ }^{101}$ Firstly, the Supreme Administrative Court, which has exclusive jurisdictional powers; this is the case in Germany. Secondly, the Conseil d'Etat with judicial and advisory responsibilities; this is the French model. Thirdly, the single Supreme Court including a specialist administrative chamber; this is the Spanish example. And, more recently, the Supreme Court, a single and undivided entity, where the same court formation hears administrative, civil, criminal or social cases; this is the British model.

\subsection{The Influence of European Laws on the French Administrative Justice}

The French administrative justice first had to evolve under a battering from the laws of the European Union and European Convention on Human Rights. In addition, it could no longer ignore other national administrative laws (European in particular), which now influence the judgments of administrative courts.

\subsubsection{The Influence of EU and ECHR Law on Administrative Justice}

While the French administrative courts only belatedly agreed to that European law should prevail over national law, ${ }^{102}$ the primacy of EU law, as interpreted by the European Court of Justice, and the acceptance of ECtHR case law, are now assured overall. The influence of these two European sources has caused significant changes to French administrative justice.

\subsubsection{The Extension of the Administrative Court's Powers}

The desire to apply the law of the European Union effectively and uniformly, with a view to ensuring the establishment of free and undistorted competition between economic operators, rather quickly resulted in a framework for the institutional and procedural autonomy enjoyed by Member States. EU law has been a transformation factor for national administrative law including "the conditions for fulfilling the court's mission; ${ }^{\prime \prime 03}$ this is reflected in various areas.

Olson Terry, Justice administrative et Constitution en Europe: état des lieux, 37, Nouveaux Cahiers du Conseil constitutionnel (2012).

101 Aguila Yann, La justice administrative, un modèle majoritaire en Europe. Le mythe de l'exception française à l'épreuve des faits, A.J.D.A. 290-294 (2007). 
Generally, in the name of the effective judicial protection of EU citizens, ${ }^{104}$ the French administrative courts have been forced to acquire powers, in particular to set aside national legislative provisions which are obstacles, even temporarily, to the full effectiveness of EU law. This same law then requires Member States to establish interlocutory proceedings affording the possibility for the court to issue interim measures to remedy the alleged violation. In Factortame ${ }^{105}$ and Zuckerfabrik, ${ }^{106}$ the Court of Justice even identified a principle of effective provisional judicial protection requiring the suspension of the operation of a national rule that is incompatible with EU law. Consequently, the suspension of proceedings existing in French administrative disputes was revised because of overly restrictive conditions for granting the suspension. This ultimately resulted in the creation of référé suspension proceedings under the Law of 30 June $2000 .^{107}$

Specifically, in the area of administrative contracts, two 'remedy' Directives ${ }^{108}$ concerning the award of public supply and public works contracts have required that Member States set up" means of effective and rapid remedies in the event of infringement of Community law on public procurement or national rules implementing that law."Thus, the French legislature established a référé précontractuel (pre-contractual application or hearing) in public procurement matters, ${ }^{109}$ which allows the administrative court to neutralise or redirect the conclusion of a public procurement contract that is on the point of being concluded, where it does not respect competition rules. In the same vein, the Conseil d'Etat established a new remedy in Société Tropic Travaux signalisation de $2007^{110}$ giving a competitor foreclosed from the market the right to bring a full remedy action. This case law has since been extended to all third parties to administrative contracts. ${ }^{111}$

104 ECJ, Case 14/83, Von Colson and Kamman [1984], ECR 01891. See also Article 47 of the Charter of Fundamental Rights of the European Union.

ECJ, Case C-213/89, Factortame [1990] I-02433.

ECJ, Joined cases C-143/88 and C-92/89, Zuckerfabrik [1991] ECR I-00415.

Cassia Paul, L'impact du droit communautaire sur le contentieux administratif 1017-1029 (J.-M. Auby et J. Dutheil de la Rochère, Droit administratif européen, 2ème éd., Bruylant, Bruxelles, 2014).

Council Directive 89/665/EEC of 21 December 1989 on the coordination of the laws, regulations and administrative provisions relating to the application of review procedures to the award of public supply and public works contracts (OJEC - L 395/33 of 30 December 1989), amended by Directive 92/50/CEE, known as 'classic sectors'; Council Directive 92/13/EEC of 25 February 1992 coordinating the laws, regulations and administrative provisions relating to the application of Community rules on the procurement procedures of entities operating in the water, energy, transport and telecommunications sectors (OJEC - L 76/14 of 23 March 1992), known as 'excluded sectors'.

Loi No. 92-10 du 4 janvier 1992 relative aux recours en matière de passation de certains contrats et marchés de fournitures et de travaux [Law No. 92-10 of 4 January 1992 on remedies in matters concerning the conclusion of certain contracts and markets for supplies and works], JORF du 7 janvier 1992, at 327. 


\subsubsection{Changes to Administrative Trials}

Many of these requirements, related to effective judicial protection, in terms of access to the courts but also the conduct of the trial, are shared by the European Convention on Human Rights.

Although the standards drawn the European Convention on Human Rights do not have the same contentious properties as EU law, they influence French administrative disputes in no small way by establishing minimum standards. Articles 6 (1) and 13 respectively enshrine the right to fair trial and the right to an effective remedy; the European Court has gradually defined the contours thereof and set requirement levels so that they are respected. While Article 6 (1) in principle covers 'civil rights or obligations' and 'any criminal charge', the European Court has interpreted these concepts broadly so to include administrative cases within the scope of that provision..$^{12}$ Moreover, the European Court has taken a broad approach to the concept of'court', impervious once again to national qualifications.

The standard of protection required by the European Convention has prompted changes in French administrative disputes. Regarding the effective access to the courts, ${ }^{113}$ the French administrative courts have agreed to hear cases previously deemed inadmissible, in order to meet the requirements of a fair trial. Owing to their effects or their gravity, certain disciplinary sanctions against prisoners or soldiers have been removed from the category of internal measures to become administrative acts that are open to challenge. ${ }^{114}$ Similarly, the administrative courts have extended their oversight of certain acts owing to the requirements of the European Convention, leading for example to passing from the review of manifest errors of assessment to normal review of disciplinary sanctions within the civil service. ${ }^{15}$

Furthermore, the jurisprudence of the European Court has also resulted in amendments to the course of administrative proceedings. While the application of Article 6 (1) essentially led to adjustments, without the functional duality of the Conseil d'Etat ${ }^{116}$ or the institution of government commissioner (now the rapporteur public $\left.{ }^{117}\right)$ being called into question on principle, the duty to make hearings public has been generalised, breaking with French legal tradition in administrative cases. ${ }^{118}$

112 Concerning the civil nature: ECtHR, Ringeisen v Austria, Application No. 2614/65, 16 July 1971; and regarding criminal charges, ECtHR, Engel v Netherlands, Application No. 5100/71, 8 June 1976.

113 ECtHR, Golder v United Kingdom, Application No. 4451/70, 21 February 1975.

114 CE, ass., Hardouin et Marie, 17 February 1995, Rec. at 82 et 85.

115 CE, ass., 13 novembre 2013, Dahan, Rec. at 279.

116 ECtHR, Sacilor-Lormines C/France, Id. Cf. above, I

117 Though this may have been thought initially following the decisions in ECtHR, Kress v France, Id.; ECtHR, Martinie v France, Application No. 58675/00, 12 April 2006. The changes made by France, establishing the rapporteur public and abolishing their participation in the debliberations was approved by the ECtHR: Etienne v France, Application No. 11396/08, 15 September 2009.

118 As regards the publicity of decisions handed down by social welfare courts, see CE, sect., 29 July 1994, Département de I'Indre, Rec. at 363. 
The influence of European law has also paved the way for State liability for judicial activity.

\subsubsection{State Liability for the Activities of Administrative Justice}

State liability may be incurred as a consequence of the malfunctions of administrative justice. ${ }^{119}$ The scenarios in which a litigant may be entitled to compensation have been expanded under the influence of European law. EU law, on the one hand, set down as a guarantee of the full effectiveness of its norms the introduction of a remedy conferring entitlement to compensation for the litigant whose rights have been infringed in the content of a breach of Community law by a Member State, ${ }^{120}$ including those instances where the breach may be imputed to a supreme court. ${ }^{121}$ This case law was received in French law by the Conseil d'Etat, which enshrined the possibility that State liability may be incurred where the content of a judicial decision, even where this is final, is vitiated by a manifest breach of EU law intended to confer rights to private individuals. ${ }^{122}$

The law of the European Convention has also led to the creation of a new compensatory remedy. Article 6 (1) requires, in compliance with the right to a fair trial, that court decisions be delivered within a reasonable period of judgment. ${ }^{123}$ Now, the violation of this period by the administrative and judicial courts allows litigants to secure a ruling as to the liability of the State, ${ }^{124}$ and damages awarded by the Tribunal des conflits since the reform introduced by the 2015 Law. ${ }^{125}$

\subsubsection{French Administrative Justice under the Influence of European Administrative} Laws

French administrative law is often presented as a model and considered historically unresponsive to comparative law. In fact, comparative law has always had its place in the debate in French administrative jurisprudence. However, today, comparative law no longer serves so much to legitimise the French model as it does to destabilise it. ${ }^{126}$ In addition, the comparative law argument is now widely used by

119

120

121

122 procédures dans les domaines de la justice et des affaires intérieures [Law No. 2015-177 of 16 February on the modernisation and simplification of law and procedures in the fields of justice and internal affairs], JORF du 17 février 2015 at 2961

Melleray Fabrice, Les trois âges du droit administratif comparé ou comment l'argument de droit comparé a changé de sens en droit administratif français 13-22 (Melleray Fabrice (dir.), L'argument de droit comparé en droit administratif français, Bruylant, Bruxelles 2007). 
the administrative courts in resolving disputes. ${ }^{127}$ This trend can be explained by the desire to develop a more efficient administrative justice, both from the perspective of economic issues and the protection of citizens' rights, so that the French system remains attractive amongst the array of European administrative laws. Faced with legal issues of increasing complexity, covering fundamental rights, constitutional review, international and European law, not to mention emerging fields such as bioethics, ${ }^{128}$ the administrative courts, and specifically the Conseil d'Etat, do not hesitate to adopt or adapt precedents generated by their European and international counterparts ${ }^{129}$. The use of comparative law is brought about by the inclusion of the French administrative justice in the European area. ${ }^{130}$

The use of comparative law has become almost a judicial reflex in resolving the most important issues decided by the Conseil $d^{\prime} E t a t,{ }^{131}$ essentially taking the form of reading the findings of rapporteurs publics. Important developments in administrative contracts, ${ }_{1}^{132}$ administrative liability ${ }^{133}$ or even the conventionality review, ${ }^{134}$ were all developed on the basis of foreign examples. ${ }^{135}$ Since 2008, the Conseil has even had a comparative law unit, consisting of a team of lawyers specialising in foreign law under the stewardship of the centre de recherches et de diffusion juridiques (centre for legal research and dissemination). This particular unit has permitted an intensification in the use of comparative law, since about $80 \%$ of the decisions handed down by the Conseil d'Etat sitting in its court formation (Assemblée et Section

127 Lichère François, The Use of Comparative Law before the French Administrative Law Courts: Or the triumph of castles over pyramids 253-265 (Ademas Mads and Fairgrieve Ducan. (eds), Courts and Comparative Law, Oxford University Press 2009).

128 As regards the lawfulness of the decision to withdraw treatment for a quadriplegic patient in a vegetative state, CE, ass., 14 February 2014, Lambert Rec. at 32 and CE, ass., 24 June 2014, Lambert, Rec. at 175.

In doing so, its role edges closer to that of the administrative court in a common law system. Cf. Stirn Bernard, Le Conseil d'État, so British? 815 (M. Ademas Mads and Fairgrieve Ducan, eds, Tom Bingham and the Transformation of the Law: a Liber Amicorum, Oxford University Press 2009).

Cf. Dutheillet de Lamothe Olivier, Comparative Law as an Essential Feature of French Public Law : The Influence of the European Union and of the European Convention on Human Rights 235-421 (Ademas Mads and Fairgrieve Ducan, eds, Courts and Comparative Law, Oxford University Press 2009).

131 A. Bretonneau, S. Dahan, D. Fairgrieve, Comparative Legal Methodolog of the Conseil d'Etat: Towards an Innovation Judicial Process? 242-252 (Ademas Mads and Fairgrieve Ducan, eds, Courts and Comparative Law, Oxford University Press 2009).

132 Regarding the opening of full remedy proceedings to a foreclosed competitor with a view to challenging an administrative contract, see CE, ass., 16 July 2007, Société Tropic Travaux Signalisation, Id.

133 Regarding State liability in the event of laws adopted contrary to France's international commitments, CE, ass., 8 February 2007, Gardedieu, Rec. at 78.

134 Regarding the constitutionality review of administrative acts transposing European Directives, CE, ass., 8 February 2007, Société Arcelor Atlantique et Lorraine, Rec. at 55.

135 Cf. Melleray Fabrice, L'utilisation du droit étranger par le Conseil d'État statuant au contentieux 779-793 (Mélanges en I’honneur du Président Bruno Genevois. Le dialogue des juges, Dalloz, Paris 2009). 
du contentieux - Assembly and Litigation Section) benefited from comparative legal research in 2014. ${ }^{136}$ The comparative law unit's role is not limited to the Conseil d'Etat's litigation functions since it also has a part to play in the context of the Conseil's advisory functions. Studies of various social topics such as electronic cigarettes or same-sex marriage were conducted out by the administrative sections. This recourse to foreign law by the administrative courts, however, has its limits in areas heavily influenced by national legal culture which preclude a comparative analysis.

Lastly, comparative law has a number of functions within the Conseil d'Etat. Firstly, it serves to strengthen or reverse the legitimacy of established case law, particularly in the context of the integration of European norms. The finding of an isolated position in relation to other foreign courts regarding the interpretation of the law of the European Union may for example lead to a long overdue reversal of precedent. ${ }^{137}$ Conversely, an analysis of judicial decisions handed down by the European courts adopting a divergent position can strengthen the Conseil d'Etat in its stance by wanting to mark stand apart on particular issues. Lastly, the comparative law argument can drive the creative force of the administrative courts and bring about changes in the state of the law on a sensitive social issue.

\section{Statistical Elements}

The Conseil d'Etat publishes an annual report on the advisory and litigation activities of administrative courts. This illustrates those activities in numbers. ${ }^{138}$

\subsection{The Conseil d'Etat's Advisory Activities in 2015}

118 bills, 68 draft orders, 4 draft laws, 800 decrees and 32 opinions were examined by the Conseil d'Etat. The average time taken to review bills is relatively short: $25 \%$ of the texts were examined in less than 4 days and $99 \%$ of texts were examined in less than two months. It is the same for the average time devoted to reviewing draft decrees: $19 \%$ were examined within four days and $86 \%$ in less than two months.

\subsection{The Jurisdictional Activities of the Administrative Courts in 2015}

Before the Conseil d'Etat, 8727 cases were filed, a decrease of $28 \%$ compared to 2014 and 9712 cases were tried, a decrease of $20.7 \%$ compared to 2014. In addition, 160

For a very recent example, concerning the export to Spain of the gametes of the applicant's dead husband so that she may proceed with a post-mortem insemination in that country, CE, 31 May 2016, Mme C., No. 396848.

137 Regarding the direct effect of European Directives, see, CE, ass., 30 October 2009, Perreux, Rec. at 407.

138 Conseil d'Etat, Le Conseil d'Etat et la justice administrative, Bilan d'activité 2015, available at <http:// www.conseil-etat.fr/content/download/61676/554062/version/2/file/bilan2015.pdf>. 
questions prioritaires de constitutionnalité were decided. The average time for judgment was 6 months and 23 days, a reduction of 38.5\% between 2005 and 2015.

Before the administrative courts of appeal, 30,597 cases were filed, an increase of $2.5 \%$ compared to 2014 and 30,540 were decided, an increase of $2 \%$ compared to 2014 . The average time of judgment is 10 months and 25 days, a $25 \%$ reduction between 2005 and 2015. Lastly, 78.9\% of the decisions of administrative courts of appeal have confirmed the decisions of administrative tribunals. $96.6 \%$ of judgments handed down by administrative courts were final, i.e. no appeal was brought against them.

Before the administrative courts, 192,007 were filed, a decrease of 1.8\% compared to 2014 with 188,783 cases decided, an increase of $0.3 \%$ compared to 2014 .The average time of judgment is 10 months and 9 days, a reduction of $36.4 \%$ between 2005 and 2015.

\section{Acknowledgments}

All our thanks to Rachael Singh, Lawyer Linguist, University of Bordeaux, for the assistance in translation of this paper from the French into the English language.

\section{References}

Bellagamba U. Le contentieux administratif en Italie au XIX siècle: modèles et pratique (Hautebert Joël et Soleil Sylvain, dir., Modèles français, enjeux politiques et élaboration des grands textes de procédure en Europe, Éditions juridiques et techniques, Tome 1, Paris 2007).

Cassia P. L'impact du droit communautaire sur le contentieux administratif (Auby Jean-Marie et Dutheil de la Rochère Jacqueline, Droit administratif européen, 2ème éd., Bruylant, Bruxelles 2014).

Le Conseil d'Etat: son histoire à travers les documents d'époque (Fougère Louis, dir., Éditions du Centre national de la recherche scientifique, Paris 1974).

Gaudemet Y. L'exportation du droit administratif français. Brèves remarques en forme de paradoxe (Mélanges Philippe Ardant, Droit et politique à la croisée des cultures, LGDJ, Paris 1999).

Traité de droit administratif (Gonod Pascal et alii (dir.), 3 Tomes, Dalloz, Paris 2011).

Guyomar Mattias et Seiller Bertrand, Contentieux administratif (Dalloz, coll. HyperCours, Paris 2014).

Mehdi Rostane, Le contentieux administratif (Droit nationaux, droit communautaire: influences croisées. En hommage à Louis Dubouis, La documentation française, Paris 2000).

Melleray Fabrice, Les trois âges du droit administratif comparé ou comment l'argument de droit comparé a changé de sens en droit administratif français in L'argument de droit comparé en droit administratif français (Melleray Fabrice (dir.), Bruylant, Bruxelles 2007) 
Melleray Fabrice, L'utilisation du droit étranger par le Conseil d'Etat statuant au contentieux (Mélanges en I'honneur du Président Bruno Genevois. Le dialogue des juges, Dalloz, Paris 2009).

La loi du 28 pluviôse An VIII deux cents ans après: survivance ou pérennité? (Mercuzot Benoît, dir., PUF, Paris 2000).

Odent Raymond, Contentieux administratif (1977) (réédition Dalloz, Paris 2007).

Olson Terry, Justice administrative et Constitution en Europe état des lieux, 37 Nouveaux Cahiers du Conseil constitutionnel (2012).

\section{Information about the authors}

Hugo Flavier (Pessac, France) - Associate Professor of Public Law and European Law, at the University of Bordeaux, Centre de Recherche et Documentation Européen et International (CRDEI) (16 Avenue Léon Duguit, Pessac, 33608, France; e-mail: hugo. flavier@gmail.com).

Charles Froger (Paris, France) - Associate Professor of Administrative Law at Paris-Sorbonne University, Centre d'études et de Recherche en Administration Publique (CERAP) (12 place du Panthéon, Paris, 75005, France; e-mail: Charles. Froger@univ-paris1.fr). 